\title{
Social-ecological resilience of small-scale coffee production in the Porce river basin, Antioquia (Colombia)
}

\author{
Resiliencia socioecológica de la pequeña producción de café de la cuenca del Río \\ Porce, Antioquia, Colombia
}

\author{
Mónica María Machado-Vargas ${ }^{1}$, Clara Inés Nicholls-Estrada'2,3, Leonardo Alberto Ríos-Osorio ${ }^{1}$
}

\begin{abstract}
This research was carried out in the Porce river basin, Antioquia (Colombia) with nine coffee growing families in charge of conventional systems and in transition to the organic production of coffee. The farms were characterized from an agroecological perspective, while evaluating the social, economic and technical-productive dimensions. It was detected that the two main threats faced by small farmers in this area are climatic variability and fluctuations in coffee prices. Using the RIH Risk Index methodology, a set of indicators was proposed to reflect the vulnerability and the response capacity of these families.
\end{abstract}

Keywords: coffee agroecosystems, indicators, sustainability, social-ecological resilience

\section{RESUMEN}

En esta investigación se llevó a cabo en la cuenca del río Porce, Antioquia, Colombia con nueve familias de pequeños caficultores convencionales y en transición a la producción orgánica. Los caficultores fueron caracterizados desde la perspectiva agroecológica, evaluando las dimensiones sociales, económicas y técnico-productivas. Se detectó dos principales amenazas que enfrentan los pequeños caficultores de esta zona son la variabilidad climática y las fluctuaciones de los precios del café. Utilizando la metodología de Índice de Riesgo IHR, se propuso un conjunto de indicadores que reflejaran la vulnerabilidad y la capacidad de respuesta de estas familias.

Palabras clave: agroecosistemas de café, indicadores, sostenibilidad, resiliencia socioecológica.

\section{Introducción}

In Colombia, coffee farming is still a smallholder production system. The characteristics of this type of system, together with the low educational level of coffee growers and their limited food and financial security, contribute to the vulnerability of coffee farming to highly volatile market conditions and the influence of external events such as droughts, frosts, special policies in some countries, among others (Abaunza et al. 2013). Hence the need to study and understand the social-ecological problems of this type of agroecosystems from an agroecological perspective with a new systemic approach.
The holistic approach that leads to the understanding of agricultural problems in systemic terms is called agroecology and it studies the socialecological relations within agroecosystems as complex adaptive systems. Therefore, a recent concern of agroecology is understanding the social-ecological resilience of agroecosystems. Social-ecological resilience, from the perspective of adaptive change, is defined as the capacity of a social-ecological system to overcome disturbances by finding diverse balance points and to maintain its essential functions and characteristics by self-regulating through adaptive processes. (Holling 2001). Although agroecology focuses on the design of agroecosystems with high

\footnotetext{
1 Grupo de investigación Salud y Sostenibilidad, Escuela de Microbiología, Universidad de Antioquia, Colombia. Medellín, Colombia.

2 Permanent lecturer University of California. Berkeley, CA. US.

3 Latin American Scientific Society of Agroecology (SOCLA). Colombia.

* Corresponding Author: monica.machado@udea.edu.co
}

Fecha de recepción: 31 marzo, 2018.

Fecha de aceptación: 21 agosto, 2018.

DOI: http://dx.doi.org/10.4067/S0718-34292018005001801. Publicado en línea: 9-enero-2019. 
resilience to climatic variability, the concept of adaptive capacity may also include the social and economic dimensions of social-ecological resilience (Speelman et al., 2014).

As to agroecosystems, knowing their levels of social-ecological resilience provides insight into their dynamics and enables the design of strategies to face current and probable future scenarios. The improvement of the social-ecological resilience of a system and the reduction of its vulnerability allows it to change from an undesirable state to a desirable one, and in some cases, can lead to transformability, understood as the capacity of communities to create new social-ecological systems when environmental, social-economic or political conditions have been the cause of transformation of the essential attribute of the agroecosystem (Altieri 2013).

Therefore, one of the challenges faced by researchers is the development of a conceptual and methodological framework to explain the key principles and mechanisms of the social-ecological resilience of agroecosystems, as well as the methodologies to assess and determine their resilience levels. The essential attribute, namely "the adaptive capacity or the response capacity of social-ecological systems", makes part of one of the proposals to assess socialecological resilience levels. It is mentioned in works by Henao (2013), Montalba et al. (2013), Altieri (2013) and Gazzano (2015) allowing the construction of a reference framework. However, this approach is rather based on ecological concepts and focuses on climatic variability, and therefore, the need to measure social dimensions is highlighted. The methodologies necessary to analyze and measure the levels of social-ecological resilience are thus being developed.

This research is aimed at assessing the level of social-ecological resilience of nine coffee agroecosystems managed by small producers in the Porce river basin in Antioquia (Colombia) to know the risk that coffee growers are facing, determine their vulnerability and response capacity levels, and propose strategies for agroecological management to increase the sustainability of vulnerable farmers.

\section{Materials and methods}

\section{Description of the study area}

This study took place in the northeast of the department of Antioquia (Colombia) in the Porce river basin, which comprises the municipalities of Gómez
Plata, Amalfi, Santa Rosa, Santo Domingo and Yolombó. This basin extends over $5920 \mathrm{~km}^{2}$, at elevations between 3600 masl and 67m masl (USGS, 2012) and with an annual rainfall between 2000 and $3500 \mathrm{~mm}$. Nine coffee growers were selected in the area, all located within the 1000 and 1800 masl and at an average temperature between the $18^{\circ} \mathrm{C}$ and $25^{\circ} \mathrm{C}$, in a premontane wet forest life zone (bmh-PM) in transition to tropical moist, in accordance with Holdridge's ecological classification. The soil in this area was classified as ustoxic dystropept with low natural fertility, good drainage, and acids (Jaramillo 1989).

\section{Selection of production systems}

Out of forty-eight coffee farmers located in the five municipalities recommended by the UMATAS (Municipality Units of Technical Agricultural Assistance), nine small coffee production systems were selected for this study, in response to their high scores on the assessment of the following inclusion systems: household composition, implementation of good agricultural practices, time allocated to farm labor, diverse income-generating activities, farm location, community participation, productive experience, water availability, loans, use of agrochemicals, suitable technologies, articulation, commercial production and conflict resolution.

\section{Assessment of risk/social-ecological resilience}

The assessment of the risk/social-ecological resilience levels of nine agroecosystems managed by small coffee growers had various stages of development. First, the agroecosystems were characterized by applying mixed methods in case studies and using social, economic and technical-productive indicators, taking an agroecological approach that allowed the identification of the critical areas of these agroecosystems (Machado-Vargas et al., 2015).

The indicators to define the social-ecological resilience of small coffee growers were established through a systematic review (Machado-Vargas and Ríos-Osorio 2016). All things considered, the social, economic and environmental indicators selected gave an account of the vulnerability and response capacity of the phenomena studied. These indicators were employed to determine the risk/social-ecological resilience levels of small coffee growers. The basis was The Holistic Risk Index (HRI) proposed by Barrera et al., (2007). This methodology allows an approach 
in order to measure resilience levels, given that it establishes the vulnerability of a particular system and its response capacity, which is a characteristic of resilience. This methodology contained three main elements to establish risk: threat, vulnerability and response capacity (or adaptive capacity), represented in the equation below:

$$
\text { RISK }=\frac{\text { THREAT }+ \text { VULNERABILITY }}{\text { RESPONSE CAPACITY }}
$$

\section{Weighting of selected indicators}

The indicators were selected according to systematic review (Machado-Vargas and Ríos-Osorio 2016). The measurements were taken between 2013 and 2015 , by means of interviews to coffee growers. The scale implemented to assess each indicator ranged from 1 to 4,4 being the highest, and 1 the lowest. The process of weighting involves taking into account the weight or relevance given to certain indicator, variable or sub indicator, in the seek for its differential assessment, and it is defined in response to the impact of the indicator on a process or phenomenon. In this research, the weighting was the coefficient by which the indicator value was to be multiplied. The most relevant indicators to analyze coffee agroecosystems found in the literature were given twice the weight (2) in this study.

Two indicators were proposed for threat:

- Water availability by rainfall: Annual rainfall in the region (Porce river basin) necessary to coffee growth, measured in millimeters.

- Fluctuations in domestic producer prices per load of coffee parchment: Domestic price issued by the FNC (National Federation of Coffee Growers of Colombia) and which is paid to the producer per each load of parchment coffee.

For the weighting, the indicator of fluctuations in domestic producer prices per load of coffee parchment had twice the weight since variability and coffee price fluctuations cause uncertainty among coffee growers about future incomes and difficulty when deciding the strategy to be followed to increase crop profitability, according to Abaunza et al. (2013). On the other hand, in Colombia, the costs of fertilizers have gone up from $10 \%$ to $20 \%$ in the last years, which has influenced the production costs of the coffee load (Abaunza et al., 2013). In general, when prices decrease and production costs increase, the capital of coffee growing families and their consumption capacity may diminish and lead to deterioration of their livelihood. The weighting for threat indicators and its assessment were carried out using this equation:

$$
\text { Threat }=\frac{(A 1+2 A 2)}{3}
$$

Where:

A1: water availability by rainfall

A2: fluctuations in domestic producer prices per load of coffee parchment

2: twice the weight

3 : sum of weighting factors

Regarding vulnerability three indicators were selected:

- Coffee productivity: $\mathrm{kg} / \mathrm{ha} / \mathrm{year}$ of dry parchment coffee, taking the performance of the Castillo variety as referent, according to the FNC.

- Food self-sufficiency in the household: food produced in the family agricultural unit to supply dietary needs of the group.

- Level of internal inputsuse: low inputtechnologies and efficient use of resources (nutrient recycling and use of sub products inside the farm).

The equation to assess the vulnerability of coffee growers in the study is:

$$
\text { Vulnerability }=\frac{(V 1+2 V 2+2 V 3)}{5}
$$

Where:

V1: coffee productivity

V2: Level of food self-sufficiency

V3: Level of internal inputs use (Dependence on external inputs)

2: twice the weight

5: sum of weighting factors

The most relevant indicators - levels of food selfsufficiency and internal input use- were given twice the weight since recent studies in Central America (Katlyn et al. 2013; Bacon et al. 2014) found that food self-sufficiency is a factor of vulnerability for small coffee growers and showed the difficulties that farmers face during certain seasons. Regarding the dependence on external inputs, some studies have compared conventional coffee systems with organic or agroecological ones in Costa Rica and Brazil, proving that crops where organic fertilizers were 
employed and which were subject to agroecological practices had higher quality soils, gave better yields, depended less on external input and could also reduce production costs, leading to improved living conditions among the growers (Souza et al., 2012).

Eight indicators were chosen for response capacity. The following equation displays how the response capacity and its indicators were assessed and weighted.

Response capacity $=\frac{(2 C 1+C 2+C 3+2 C 4+C 5+2 C 6+C 7+2 C 8)}{12}$

Where:

$\mathrm{C} 1: \%$ of shade trees for coffee plantations

C2: Soil cover

C3: Surrounding landscape diversity

C4: Productive diversity of production systems

(coffee and others)

C5: Autonomy from markets.

C6: Level of training on agroecological knowledge

C7: Level of productive organization for commercialization

C8: Level of organization aimed at rural community development

2: twice the weight

12: sum of the weighting factors

For the weighting, the indicators given the highest values were $\mathrm{C} 1, \mathrm{C} 4, \mathrm{C} 6$, and $\mathrm{C} 8$. Regarding $\mathrm{C} 1$ - the percentage of shade trees for coffee plantations recent studies by Cerdán et al. (2012) and Souza et al. (2012) have proven that the agroforestry systems of coffee provide ecosystem services, such as biodiversity preservation, erosion control, increased soil quality, carbon sequestration, moderation of temperature extremes, lower evapotranspiration and higher preservation of soil moisture, just as timber trees may represent another source of income and fruit trees may contribute to food security (Cerdán et al. 2012). About C4 - Productive diversity of production systems (coffee and others) - some studies (Hauserman 2014) have revealed that low coffee prices worldwide and high production costs have caused coffee growers to appeal to other income activities that entail the diversification of their production systems and include the sale of other products (vegetables, fruits, milk, etc.) as strategies to face vulnerability (Speelman et al. 2014).

When it comes to C6 - level of training on agroecological knowledge - coffee growers that know about agroecology and carry out the relevant practices in their lands are able to obtain higher yields from their systems, greater environmental benefit and human health (Bacon et al. 2014). Besides decreased production costs, which generate less dependence on external inputs, agroecology offers advantages to the families related to the relative autonomy from input markets - when local resources are employed instead of purchased inputs -, from food markets - greater provision through diverse markets and products for self-sustenance - and from local or organic markets. (Nicholls et al. 2016).

Finally, for $\mathrm{C} 8$ - level of organization aimed at rural community development - the coffee growers that make part of organizations - fair market and certification - and of social networks have the possibility to become less vulnerable, improve their food intake habits and living conditions, as well as face crises collectively (Bacon et al. 2014).

\section{Results and discussion}

\section{Description of the study population}

The characteristics of the nine agroecosystems selected are described in Table 1. The main crops in these production systems are coffee grown without shade and under partial shade. These systems commercialize coffee with the FNC and include secondary crops and some minor species, as well as other food security and economic alternatives.

\section{Risk index}

The results of the threat, vulnerability, and response capacity indexes are shown in Figures 1,2 and 3. For better understanding, the vulnerability index is represented as low or high, since the corresponding indicators were scored with 1 when very low and 4 when high. In the result of the equation of threat, vulnerability and response capacity, the standard established was 1 , where values $>1$ represented more vulnerability and higher risk, causing socialecological resilience to decrease. Values near zero represented a lower risk and hence, increased socialecological resilience (Henao 2013).

For this assessment, it was determined that all threats are the same for all coffee growers, therefore, it was considered a constant variable equal to 1 . The average rainfall in the Porce river basin in 2013 came from six meteorological stations (information supplied by EEPP of Medellin). The lowest rainfall levels were observed in January, June, July, and 
Table 1. Brief description of the nine farms selected in the Porce river basin, northeast of Antioquia

\begin{tabular}{|c|c|c|c|}
\hline Agroecosystem & Municipality & Type of management system & Property description \\
\hline A1 & Amalfi & Transition-organic & $\begin{array}{l}\text { Area: } 3.5 \mathrm{~h} \text {, Altitude: } 1,470 \text { masl } \\
\text { Temperature: } 21-22^{\circ} \mathrm{C} \\
\text { Main crop: coffee (Castillo and Caturro) association } \\
\text { with "guamo" (Inga spuria), plantain, avocado and } \\
\text { soursop trees. }\end{array}$ \\
\hline A2 & Amalfi & Transition-organic & $\begin{array}{l}\text { Area: } 0.36 \mathrm{~h} \text {, Altitude: } 1,470 \text { masl } \\
\text { Temperature: } 21-22^{\circ} \mathrm{C} \\
\text { Main crop: coffee (Castillo, Catimoro and Caturro) } \\
\text { association with "guamo" (Inga spuria), plantain, } \\
\text { avocado and soursop trees. }\end{array}$ \\
\hline A3 & Gómez Plata & Conventional & $\begin{array}{l}\text { Area: } 2.6 \mathrm{~h} \text {, Altitude: } 1,500 \text { masl } \\
\text { Temperature: } 20^{\circ} \mathrm{C} \\
\text { Main crop: coffee (Rosario, Castillo and } 2,000 \\
\text { variety) association with plantain. }\end{array}$ \\
\hline A4 & Gómez Plata & Conventional & $\begin{array}{l}\text { Area: } 4.0 \mathrm{~h} \text {, Altitude: } 1,025 \text { masl } \\
\text { Temperature: } 22-24{ }^{\circ} \mathrm{C} \\
\text { Main crop: Sugarcane and coffee (Rosario, Castillo } \\
\text { and } 2,000 \text { variety) association: plantain. }\end{array}$ \\
\hline A5 & $\begin{array}{c}\text { Santo } \\
\text { Domingo }\end{array}$ & Transition-organic & $\begin{array}{l}\text { Area: } 7 \mathrm{~h} \text {, Altitude: } 1,200 \text { masl } \\
\text { Temperature: } 27^{\circ} \mathrm{C} \\
\text { Main crop: Castillo coffee variety without association }\end{array}$ \\
\hline A6 & $\begin{array}{c}\text { Santa Rosa de } \\
\text { Osos }\end{array}$ & Conventional & $\begin{array}{l}\text { Area: } 5 \mathrm{~h} \text {, Altitude: } 1,300 \text { masl } \\
\text { Temperature: } 22^{\circ} \mathrm{C} \\
\text { Main crop: coffee (Castillo and Colombia varieties) } \\
\text { association with plantain and cassava. }\end{array}$ \\
\hline A7 & $\begin{array}{c}\text { Santa Rosa de } \\
\text { Osos }\end{array}$ & Conventional & $\begin{array}{l}\text { Area: } 2 \mathrm{~h} \text {, Altitude: } 1,500 \text { masl } \\
\text { Temperature: } 20^{\circ} \mathrm{C} \\
\text { Main crop: coffee (Castillo, Caturro and Colombia) } \\
\text { association with plantain and cassava }\end{array}$ \\
\hline A8 & Yolombó & Transition-organic & $\begin{array}{l}\text { Area: } 8 \mathrm{~h} \text {, Altitude: } 1,320 \text { masl } \\
\text { Temperature: } 22^{\circ} \mathrm{C} \\
\text { Main crop: coffee (Pajarito, Castillo and Colombia) } \\
\text { association with plantain, "guamo" (Inga spuria), } \\
\text { "yarumo" (Cecropia peltata) and "nogal cafetero" } \\
\text { (Cordia alliodora) }\end{array}$ \\
\hline A9 & Yolombó & Transition-organic & $\begin{array}{l}\text { Area: } 7 \mathrm{~h} \text {, Altitude: } 1,400 \text { masl } \\
\text { Temperature: } 22-25^{\circ} \mathrm{C} \\
\text { Main crop: coffee (Catimore, Castillo and Colombia) } \\
\text { association with plantain " "guamo" (Inga spuria) and } \\
\text { "nogal cafetero" (Cordia alliodora). }\end{array}$ \\
\hline
\end{tabular}

December. It is worth highlighting that the El Niño phenomenon that hit the region in 2012 lasted until January-February 2013 (IDEAM 2012). Although 2013 was a normal year according to the IDEAM, the average rainfall in the Andean region decreased in a 75\% throughout June and July (IDEAM 2013). The average rainfall in the basin during 2013 was $202 \mathrm{~mm}$, far below the average for coffee farming (1200-1800 mm) (García et al. 2015). The sampling, which was carried out during June and July 2013, shows it to be below the optimal level for coffee farming since these were the months that saw the lowest rainfall in the region. Besides, the Porce region is characterized by high evapotranspiration and solar radiation, which together with an average temperature between $16{ }^{\circ} \mathrm{C}$ and $24^{\circ} \mathrm{C}$ that reaches a maximum of $30^{\circ} \mathrm{C}$, contributes to high vulnerability for the coffee production in the region.
Regarding the indicator fluctuations in domestic and external producer prices per load of coffee parchment for coffee growers, the results showed that in 2013 the prices had a major drop at the end of the year (Figure 1). Likewise, the earnings decreased dramatically, which means that the profit for coffee growers was then far below the balance point - COP $\$ 500000$ - translating into loss for coffee families. By June, the profit per load was COP $\$ 79888$ and it kept dropping until early 2014. This happens when the external price of coffee decreases and the coffee growers cannot afford internal inputs (fertilizers and pesticides). Earlier in 2014, the drop in prices caused a national strike and demonstrations carried out by coffee growers, who demanded a government subsidy by coffee load sold which allowed to cover the difference between the grain production price in the market and the actual costs of production (Pérez et al. 2016). 


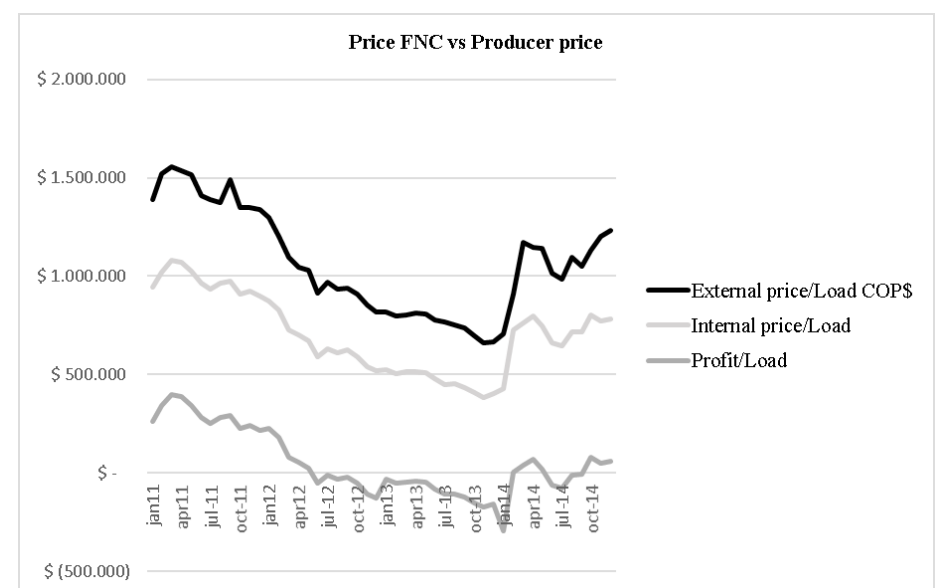

Figure 1. Fluctuation of external and internal prices per load between 2011 and 2014; profits of coffee farmers during the same period. Values negative was far below the balance point COP $\$ 500.000$ (peso colombiano) (Source: FNC).

\section{Vulnerability index}

Considering the vulnerability index, the agroecosystems A1, A3, and A7 were the most vulnerable (Figure 2). These production systems had low scores on the level of the indicator offood self-sufficiency and level of internal inputs use. Coffee growers do not supply their own food and the agricultural inputs employed in their farms come from external sources since they do not make use of the crop residues nor the domestic waste to make their own inputs. Likewise, they do not carry out recycling practices within the farm, which could lead them to a decreased coffee production and to become more vulnerable to production costs. Studies in Central America have proven that the main vulnerability factors of small coffee growers are food insecurity (represented in a period of famine) and the dependence on external inputs (fertilizers and pesticides), together with longterm instability of the coffee harvest and price variations (Katlyn et al. 2013; Bacon et al. 2014).

On the other hand, the agroecosystems A8, A5, and A6 displayed low vulnerability. These productive systems had high and low scores at the level of food self-sufficiency given the internal production of their own food supply. Despite having been "trained" on agroecological concepts, some of the coffee growers do not implement agroecological practices such as green manures, compost preparation, and bio fertilizers, among others that would allow them to decrease the consumption of external inputs to a significant extent.

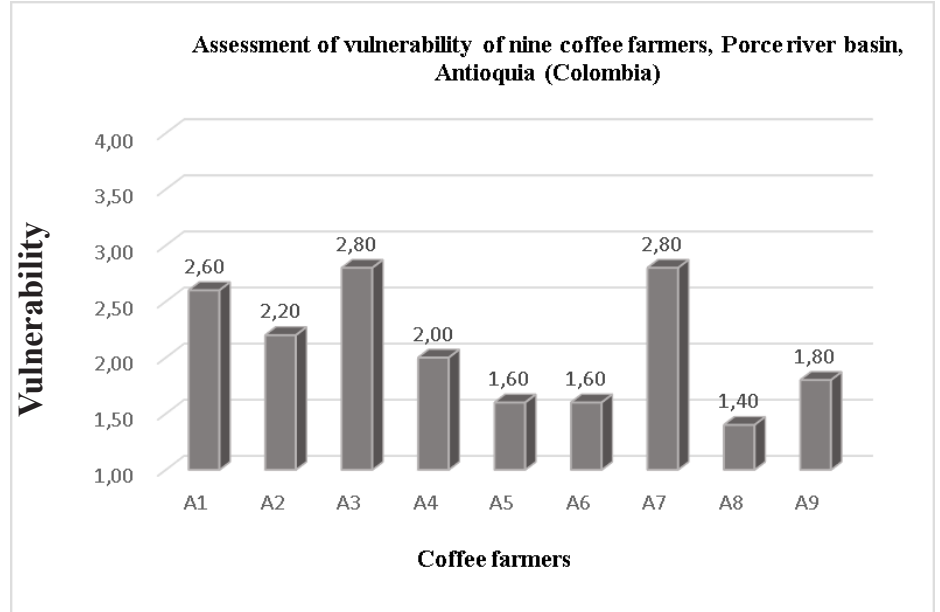

Figure 2. Level of vulnerability of nine coffee farmers in the Porce river basin. 


\section{Response capacity}

Figure 3 shows the response capacity of the agroecosystems assessed, where the coffee without shade production systems exhibit the lower levels of responsecapacity (A3, A6, and A7), except for A4, which includes sugar cane crops and livestock activities besides coffee farming. In the same way, these agroecosystems had lower scores in the indicators of autonomy from markets, level of productive organization and level of territorial organization. On the other hand, the agroecosystems with a high response capacity were A5, A8, and A9. These showed higher levels of productive diversity given the secondary crops managed for sale together with coffee. The indicator autonomy from markets showed a medium level in the A9, since the coffee grower sells the product to the coffee growers committee, but sells his secondary crops directly to a store where he is a partner. The agroecological knowledge reached medium levels in the three systems and the level of production organization reached high in A5 and medium in A9. The agroecosystems with high vulnerability and low response capacity will have to face risk, while the vulnerable agroecosystems with high response capacity decrease risk, as this study and others, show (Henao 2013; Montalba et al. 2013).

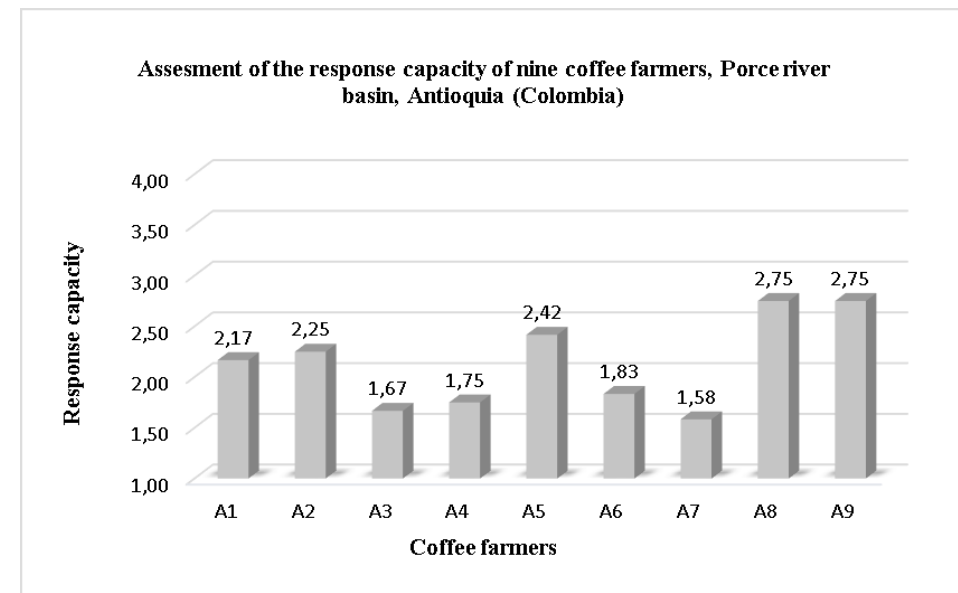

Figure 3. Level of response capacity of the nine coffee farmers studied in the Porce river basin.

\section{Assessment of social-ecological resilience through the Risk Index (HRI)}

The HRI values obtained in this study contribute to the construction of a model to establish levels of social-ecological resilience. In Table 2 can be observed that the risk level scale is based on Altieri (2013), Henao (2013), Montalba et al. (2013) and Gazzano et al. (2015), but it has been modified according to the objectives of this research.

Table 2. Relation between HRI values and Risk level and Social-ecological resilience levels.

\begin{tabular}{ccc}
\hline HRI Value & Risk level & Social-ecological resilience level \\
\hline $0<1$ & Very low & Very high \\
$1-1.5$ & Low & High \\
$1.5-2$ & Medium & Medium \\
$>2$ & High & Low \\
\hline
\end{tabular}

Source: Altieri (2013); Henao (2013); Montalba et al., (2013) and Gazzano et al., (2015), modified.
The IRH values and the social-ecological resilience levels corresponding to each agroecosystem show two agroecosystems with low resilience, other two with medium resilience, four with high resilience and one with a very high level. Altieri (2013) says that lower risk levels respond to high social-ecological resilience and higher risk levels to low social-ecological resilience (Table 3).

The agroecosystems A3 and A7 showed low levels of social-ecological resilience since they proved to be highly vulnerable and to have low response capacity. The weaknesses of these agroecosystems are their low productive diversity and high dependence on external inputs, as well as the lack of both food self-sufficiency and autonomy from markets. Also, their exclusive dependence on the sale of coffee to the FNC makes them more vulnerable to the threat of the fluctuations in the international market prices. According to Rahn et al. (2013), it is possible to mitigate and adapt to the effects of price variation 
Table 3. HRI values, Risk level and Social-ecological resilience (RS) levels of the nine coffee-growing families in the study (values higher than 2 represent high vulnerability and low social-ecological resilience levels.)

\begin{tabular}{lccccccccc}
\hline Farmers & $\mathbf{A 1}$ & $\mathbf{A 2}$ & $\mathbf{A 3}$ & $\mathbf{A 4}$ & $\mathbf{A 5}$ & $\mathbf{A 6}$ & $\mathbf{A 7}$ & $\mathbf{A 8}$ & $\mathbf{A 9}$ \\
\hline Risk Index & 1.66 & 1.42 & 2.28 & 1.71 & 1.08 & 1.42 & 2.40 & 0.87 & 1.02 \\
\hline Risk level & Medium & Low & High & Medium & Low & Low & High & Very low & Low \\
\hline RS Level & Medium & High & Low & Medium & High & High & Low & Very high & High \\
\hline
\end{tabular}

by increasing productive diversity. Nicholls et al. (2016) say that the application of agroecological principles may help the systems to gain the three types of autonomies, namely, autonomy from the market employment of resources from the surroundings, instead of their purchase -, autonomy from the food markets -food self-sufficiency- and autonomy from international markets, together with the redirection of products to local or organic markets.

The production of coffee without shade and the low landscape diversity of the surroundings also make the systems more vulnerable to climatic variability, since it has been showed that the agroforestry systems of coffee and the forest parcels within the farms help to reduce $\mathrm{CO}_{2}$ emissions, increase carbon sequestration and also protect them against heavy storms (Rahn $e t$ al. 2013). Other studies have highlighted the synergy between mitigation and adaptation in agroforestry systems and forest parcels. Because of the reduced evapotranspiration observed in such systems, the organic matter in the soils favors water storage in drought times and at the same time, benefits the life conditions of coffee growers (Lin 2011). Rainfall variation and the way it can affect coffee blooming and bean ripening cycles cause concern. The ensuing production outside the phenological times of coffee leads to additional efforts during harvest, higher production costs, and impacts on the economic viability of coffee cultivation (Rahn et al. 2013). Hence, there is a need to redesign monoculture plantations of coffee without shade into agroforestry systems managed under agroecological principles.

In the agroecosystems A1 and A4, the level of social-ecological resilience was medium. However, their levels of vulnerability were high and their response capacity allowed them to face the low water availability during June and July with ground cover practices and productive diversity in their farms, however, it is worth mentioning that it is important to think about the improvement of the systems through redesign aimed at reducing vulnerability to future events.
The agroecosystems A2, A5, A6 and A9 showed high levels of social-ecological resilience, while A8 displayed a very high level. These agroecosystems showed low vulnerability and high response capacity. Their high and medium self-sufficiency, good soil cover, productive diversity - except for A6 - and level of productive organization was also noticeable.

The productive diversity of coffee agroecosystems has positively affected the coffee growing sector in Colombia, since the workforce coming from homes of small coffee growers is currently getting involved in activities other than coffee - with greater stability and higher remuneration - as it is the case of fruit and plantain trees, generating employment within the agricultural sector (CONPES 2013). In turn, this is related to the fact that there has not been a generational replacement in the Colombian coffee growing sector (CONPES 2013); as this study shows, there is a process of "decreasing peasantry", or in other words, the youth do not bear any hope on the field and migrate to cities in the search of improving their economic conditions.

On the other hand, it is important to mention that the level of organization aimed at rural development, with institutions that support the construction of resilience from agro-ecological and social perspectives, is a low indicator for the nine coffee growers. Although there are non-governmental institutions in the region such as the ecological and cultural foundation Penca de Sabila and the Agroecological Association of Farmers of the Boquerón region, the coffee growers in this study do not interact with them. There is neither a consensus about how coffee systems should be transformed in the region, nor how agricultural policies should support or strengthen coffee growers. In fact, the presence and support of governmental institutions that contribute to systems becoming more diverse and resilient is pivotal for building social-ecological resilience. Some examples in Central America, Mexico and Brazil have evidenced the role of non-governmental institutions, with an agroecological approach, in the transformation of the livelihood of farmers, and even in sustainable 
rural developments in the region (Altieri and Toledo 2011).

Likewise, it is worth noting that the indicator of agroecological knowledge reached a medium level in all agroecosystems, since all coffee growers have been trained on organic and agroecological agriculture by public institutions such as CORANTIOQUIA (Antioquia Regional Autonomous Corporation), however, as it can be observed in this study, it is not enough to have agroecological training if knowledge is not put into practice.

All coffee growers in this research are members of the FNC and have documents that identify them as such. The institution helps them to commercialize the coffee grain but it does not motivate them or train them to produce organic or special kinds of coffee, nor to build social-ecological resilience. Agroecological knowledge is important to strengthen coffee growers and other actors in the territory intellectually, helping to create empowerment and to solve concrete problems of the region (Nicholls et al. 2016).

Even if some agroecosystems were found to be socio-ecologically resilient in this study, it is important to emphasize that the agroecological approach considers it possible to have access to crucial elements such as the resilience of an agroecosystem, food sovereignty, energy sovereignty -the right of the rural population to generate energy from sustainable sources- and technological sovereignty by optimizing all the processes and resources of the farm (Nicholls et al. 2016).

A system is socio-ecologically resilient when it appeals to adaptive strategies that cause the vulnerability of the system against possible risks to decrease. Among the strategies that could be suggested in the case of coffee agroecosystems we can mention the diversification of production systems and surrounding landscape; the establishment of agroforestry systems; practices of resource optimization in the farm; agro-ecological practices; social organization; the establishment of social networks; and the promotion of autonomy from external markets and rural multi-functionality.

The results suggest that there are differences regarding vulnerability and risk, although not significant, between conventional systems and those in transition to organic production. This is coherent with other research works that suggest that agroecological systems are more resilient (Nicholls et al. 2016), considering resilience as the central element of the sustainability of a productive system, which allows it to maintain and preserve its essential attributes over time, such as soil quality, productivity and improved livelihood of farmers, among others.

In the end, agroecology fundamentally fosters adaptive strategies to design more resilient systems, able to cope with the various hazards related to the production in the field such as new pests/diseases, extreme climatic events, fluctuations in the prices of products in national and international markets, and economic and social changes that small farmers have to face. In that sense, agroecology and its various proposals for the construction of social-ecological resilience stand as a strategy for building sustainable livelihoods in rural communities.

\section{Conclusions}

In this study, the results showed that less resilient coffee agroecosystems presented low production diversity, high dependence on external inputs, lack of food self-sufficiency and lack of autonomy with respect to markets. In contrast, agroecosystems with higher levels of resilience showed high and medium food self- sufficiency, productive diversity and good levels of productive organization. This confirms that the productive diversity and food self-sufficiency of coffee growers are adaptive strategies that serve the reduction of vulnerability to fluctuations in international coffee prices.

The low level of territorial organization in all agroecosystems obtained in this study proved that participation of farmers in institutions that promote autonomy, empowerment, and governance within the community is essential so that farmers can build socioecological resilience. Regarding the level of training in agroecological knowledge, this research shows that it is not enough to have training if farmers do not conceive the management of natural resources and sustainability as part of their daily life. Therefore, it is better to raise awareness and to qualify, especially through demonstration.

The main threat faced by small farmers is the fluctuation of producer prices, since these are related to high production costs, and thus to the profitability of the crop. This study found a high dependence of coffee growers on external inputs, which makes them more vulnerable to the aspects mentioned above.

It should be considered that the attributes of the indicators need to be weighted for a greater sensitivity of the level of risk/resilience. In that sense, the actors involved at a local level should be the ones to give weight to the attributes according to their reality and select the indicators in agreement with 
the communities involved. On the other hand, it is necessary to carry out more field studies that allow the further validation and precision of the measurement scale and instrument of social-ecological resilience, so that they can be employed in different agricultural systems.

\section{Literature cited}

Abaunza, O. F.; Arango, A.S.; Olaya, M.Y.

2013. Estrategias de inversión para pequeños caficultores colombianos: Una aproximación con dinámica de sistemas. Universidad Nacional de Colombia, Comisión para la celebración del Bicentenario de la Independencia. Bogotá, Colombia. 126p.

Altieri M.A.; Toledo V.

2011. The agroecological revolution in Latin America: rescuing nature, ensuring food sovereignty and empowering peasants. The Journal of Peasant Studies, 38 (3): 587-612.

\section{Altieri, M.A.}

2013. Construyendo resiliencia socio-ecológica en agroecosistemas: algunas consideraciones conceptuales y metodológicas. eds. C. I. Nicholls, L. A. Ríos-Osorio and M. A. AltieriMedellínIn Agroecología y resiliencia socioecológica: adaptándose al cambio climático, REDAGRES, CYTED y SOCLA. Colombia. pp. 94-104.

Bacon C. M.; Sundstrom, WA.; Flores, GM.E.; Méndez, V.E.;

Santos, R.; Goldoftas, B.; Dougherty, I.

2014. Explaining the 'hungry farmer paradox': Smallholders and fair trade cooperatives navigate seasonality and change in Nicaragua's corn and coffee markets. Global Environmental Change, 25: 133-149.

Barrera, J. F.; Herrera, J.; Gómez, J.

2007. Riesgo-vulnerabilidad hacia la Broca de café bajo un enfoque de manejo holístico. eds. J. F. Barrera, A. García, V. Domínguez, and Luna C. In La broca del café en América tropical: hallazgos y enfoques. Sociedad Mexicana de Entomología y El Colegio de la Frontera Sur. México.pp. 131-141.

Cerdán, C. R.; Rebolledo, M.C.; Soto, G.; Rapidel, B.; Sinclairet, F.L. 2012. Local knowledge of impacts of tree cover on ecosystem services in smallholder coffee production systems. Agricultural Systems, 110: 119-130.

\section{CONPES.}

2013. Una estrategia para la competitividad de la Caficultura Colombiana-Comisión de Expertos. Consejo Nacional de Política Económica y Social República de Colombia, Departamento Nacional de Planeación, Bogotá, Colombia. 33p.

García, L. J. C.; Posada, S.H.E.; Salazar, V.F.A.

2015. Factores de producción que influyen en la respuesta de genotipos de Coffe arabica L. bajo diversas condiciones ambientales de Colombia. Cenicafé 66, (2): 30-57.

Gazzano, I.; Altieri, M.; Achkar, M.; Burgueño, J.

2015. Holistic Risk Index: A case study of cattle producers in the protected área of Farropos Estuaries-Uruguay. Agroecology and Sustainable Food Systems, 39 (2): 209-223.

Hauserman, $\mathrm{H}$.

2014. Maintaining the Coffee Canopy: Understanding Change and Continuity in Central Veracruz. Human. Ecology, 42:381-394.
Henao, A.

2013. Propuesta metodológica de medición de la resiliencia agroecológica en sistemas socio-ecológicos: un estudio de caso en los Andes Colombianos. Agroecología, 8 (1): 85-91.

Holling C.

2001. Understanding the complexity of economic, ecological and social systems. Ecosystems, 4: 390-405.

Instituto de Hidrología, Meteorología y Estudios Ambientales. 2012. Boletín informativo sobre el monitoreo de los Fenómenos de variabilidad climática "El Niño" y "La Niña". Boletín No. 50. IDEAM. 5p.

Instituto de Hidrología, Meteorología y Estudios Ambientales. 2013. Boletín informativo sobre el monitoreo de los Fenómenos de variabilidad climática "El Niño" y "La Niña". Boletín No. 53. IDEAM. 4p.

Jaramillo, D.

1989. Estudio general de suelos, erosión y uso potencial agropecuario para los proyectos hidroeléctricos Porce II y Porce III. Empresas Públicas de Medellín, Colombia. 99p.

Katlyn S. M.; Mendez, V.E., Olson, M.B.

2013. 'Los meses flacos': seasonal food insecurity in a Salvadoran organic coffee cooperative. The Journal of Peasant Studies, 40 (2): 457-480.

Lin, B.

2011. Resilience in agriculture through crop diversification: Adaptive management for environmental change. BioScience, 61 (3): 183-193

Machado-Vargas, M.; Nichoolls, C.I.; Márquez, S.M.; Turbay, S. 2015. Caracterización de nueve agroecosistemas de café de la cuenca del río Porce, Colombia, con un enfoque agroecológico. Revista IDESIA, 33 (1): 69-83.

Machado-Vargas, M.; Ríos-Osorio, L.A.

2016. Sostenibilidad en agroecosistemas de café de pequeños agricultores: revisión sistemática. Revista IDESIA, 34 (2): 3-11.

Montalba, R.; García, M.; Altieri, M.; Fonseca, F.; Vieli, L.

2013. Utilización del Índice Holístico de Riesgo (IHR) como medida de resiliencia sociecológica a condiciones de escasez de recursos hídricos. Aplicación a comunidades campesinas e indígenas de la Araucanía, Chile. Agroecología, 8 (1): 63-70.

Nicholls, C. I.; Altieri, M.; Vazquez, L.

2016. Agroecology: Principles for the Conversion and Redesign of Farming Systems. J. Ecosys Ecograph S5: 010. doi:10.4172/2157-7625.S5-010, 2-8.

Peréz, A.; Rosique, G.J.; Turbay, S;Machado-Vargas, M.

2016. Estudio de la seguridad alimentaria y nutricional de unidades campesinas productoras de café en rediseño agroecológico (cuenca del río Porce, Antioquia). Agroalimentaria, 22 (42): 171-189. 
Rahn, E.; Läderach, P.; Baca, M.; Cressy, C.; Schroth, G.; Malin, D.; Rikxoort van, H.; Shriver, J.

2013. Climate change adaptation, mitigation and livelihood benefits in coffee production: where are the synergies? Mitig Adapt Strateg Glob Change, 19: 1119-1137.

Souza, H. N. de; Goede, R. G. M. de; Brussaard, L.; Cardoso, I.M.; Duarte, E.M.G.; Fernandes, R.B.A.; Gomes, L.C.; Pulleman, L.L.

2012. Protective shade, tree diversity and soil properties in coffee agroforestry systems in the Atlantic Rainforest biome. Agriculture, Ecosystems and Environment, 146: 179-196.
Speelman E.N.; Groot, J. C. J.; García-Barrios, L.E.; Kok, K.; Keulen van, M., Tittonell, P.

2014. From coping to adaptation to economic and institutional change -Trajectories of change in land-use management and socialorganization in a Biosphere Reserve community, Mexico. Land Use Policy, 41: 31-44. 
